Article

\title{
Sustainable Development of an Organic Agriculture Village to Explore the Influential Effect of Brand Equity from the Perspective of Landscape Resources
}

\author{
Ching-Cheng Shen, Yen-Rung Chang * and Der-Jen Liu \\ Graduate Institute of Tourism Management, National Kaohsiung University of Hospitality and Tourism, \\ Kaohsiung 812, Taiwan; sccheng@mail.nkuht.edu.tw (C.-C.S.); mayor520212@yahoo.com.tw (D.-J.L.) \\ * Correspondence: yenrung@gmail.com
}

Received: 23 August 2020; Accepted: 7 September 2020; Published: 9 September 2020

check for updates

\begin{abstract}
Luoshan Organic Agriculture Village was the first organic agriculture village in Taiwan, and it focuses on organic farming and cultivation. The village is developed through community empowerment and the utilization of existing tourism resources. In this study, tourists to the village were selected to participate in a survey. The findings indicated that country landscape resources scored the highest, followed by experience of organic farming and natural landscape resources. The results revealed that this travel destination enjoys high brand equity, with the factor of environmental sustainability scoring the highest, followed by the uniqueness of organic farming and the image of healthy tourism. This study suggested that landscape resources were positively correlated with brand equity; moreover, access to environmental information had a significant effect on the relationship between landscape resources and brand equity. Subsequently, the top three factors affecting landscape resources were identified-natural landscape resources, experience of organic farming, and experience of farm stays. In addition, the two factors influencing brand equity of quality and unique resources were derived. This study's results can help related organizations effectively establish landscape resources, thereby extending their brand equity and building the sustainable development competitiveness of tourist destinations.
\end{abstract}

Keywords: landscape; brand equity; organic agriculture

\section{Introduction}

In recent times, rapid developments in technology have led to a prosperous society. Nevertheless, technology has had a negative effect on the environment through endangering natural ecosystems. Industrial development has caused environmental pollution. Furthermore, people who live in urban areas are inclined to desire a clean, pleasant, and comfortable environment in which to relax. Moreover, people's focus on environmental and economic factors has notably increased [1,2]. Additionally, an appreciable change has occurred in people's attitudes toward nature, healthy eating, and regiment [3]. To address the necessity of protecting the environment and maintaining ecological balance, the development of organic agriculture has become an attractive option.

In addition, the organic food market has rapidly expanded, and the demand for greener produce is increasing. Organic farming, agricultural products, villages, and agritourism have been presented as market opportunities for the organic market [1]. In 1996, Taiwan's government began promoting organic agriculture. According to statistics published by the Taiwan Organic Information Portal, a single plot of farmland has increased from 159.6 hectares to 8759.06 hectares [4], equaling an average annual increase of $19.97 \%$ hectares. Increasing awareness of eco-friendly behaviors, healthy lifestyles, sustainability, and slow movement indicates that the prospects of organic agriculture in Taiwan are brightening. 
To promote organic farming, Taiwan's government spared no efforts in establishing the first organic agriculture village in 2002. This village, located in Hualien County's Luoshan Village, was aimed at promoting community development in various manners. From an economic perspective, a strong agricultural sector contributes to a strong economy; from a livelihood perspective, organic agriculture villages aim to enhance farmers' welfare; and from an ecological perspective, organic agriculture villages are not only set up to preserve pristine environments but also to improve the relationship between humans and nature. The International Federation of Organic Agriculture Movements proposed four principles, namely: health, ecology, fairness, and care [5]. These principles indicate that health is integral to living systems. Those involved in organic agriculture treat the health of soil, animals, people, and the planet as inseparable and seek to ensure fairness at all levels. Organic agriculture should protect and care for the health and well-being of the current generation as well as of the environment for the next generation.

Recently, with increases in people's income, the popularity of domestic travel within Taiwan has grown. From 2010 to 2018, the number of visitors increased from 191,302,739 to 281,151,830 [6]. In addition, according to a 2018 survey on Taiwanese tourism, $2.7 \%$ of Taiwanese tourists sought to enjoy ecological tourism, whereas $1.9 \%$ experienced rural tourism, which saw an increase of $46.15 \%$ compared with $1.3 \%$ in 2011 . Therefore, farming and agricultural tourism has received increasing attention from people, indicating that organic agriculture village tourism is crucial and has prospects for development.

Landscape resources can be divided into entity and nonentity resources, natural landscapes and cultural landscapes [7], tangible landscapes and intangible landscapes, and resources with inherent meaning and resources with symbolic meanings. These divisions reflect the interaction between people and the environment, which is a dynamic system that changes with time and continues to develop [8,9]. Bastian et al. [10] indicated that the attraction of landscapes and nature is the most crucial reason for tourism, particularly in relation to experiencing nature and enjoying quietness and leisure time. Dai et al. [11] considered that, from a conventional landscape-resource perspective, tourists' perceptions of landscapes were lacking; tourists can value landscape resources only when they have a mindscape of landscape resources. Therefore, the landscape resources of a tourist destination are a critical type of tourism resource. Accordingly, crucial research topics for the development of tourist-consumption landscapes are: how to shape a landscape for tourist-consumption, establish a unique tourism product, build a unique attraction for a landscape based on tourists' perceptions and experience that landscape, as well as motivating tourists to recognize and rely on a tourist destination and product, and establishing the uniqueness and brand equity of a tourist destination.

In terms of marketing strategies, brand equity is an effective tool for enhancing competitive differentiation [12-14]. Establishing a unique tourism brand is a critical factor for sustainable development [15]. However, no systematic research has been conducted on the brand equity of tourist destinations $[15,16]$. Most studies on the brand equity of tourist destinations have focused on the assessment of brand equity [15], whereas few studies have explored the relationship between the landscape resources of tourist destinations and brand equity. Establishing landscape resources is a key factor for shaping unique brand equity.

Therefore, organic agritourism has become a critical market to be developed. This empirical study investigated tourists in Luoshan Organic Agriculture Village and revealed that landscape resources were positively correlated with brand equity. This study enables further understanding of the importance of brand equity dimensions and landscape resources, which can be referenced for the future brand equity development of organic agriculture villages. 


\section{Literature Review}

\subsection{Landscape}

According to Oxford Dictionaries, a landscape is a picture representing an area of the countryside. Furthermore, landscape refers to natural terrain and topography. Sauer [7] indicated that the study of landscapes originated in Germany, where landschaftskunde means knowledge of land. Sauer, in his book The Morphology of Landscape, defined a landscape as the combined physical representation of both natural and cultural elements. He stated that a landscape is an organic unit on the Earth's surface where land and living beings are interconnected. Such a region has its own unique morphology, structure, and functions. In Readings in Cultural Geography, Wagner and Mikesell [17] defined the cultural landscape as follows:

The cultural landscape is a concrete and characteristic product of the complicated interplay between a given human community, embodying certain cultural preferences and potentials, and a particular set of natural circumstances. It is the heritage of many eras of natural evolution and of many generations of human effort.

Daniel and Cosgrove [18] suggested that a landscape is a cultural image, an illustrated method of representing, structuring, or symbolizing surroundings. Stamp [19] argued that a landscape represents the visible features of an area, including virtual and cultural dimensions. Moreover, landscape refers to the surface features of an area [20] and reflects the interactions between people and their living environment, as well as the outcome of a dynamic system that grows and evolves over time [8,9]. In addition, a landscape does not only involve how people view an area but also how they describe the place and experience its cultural elements [21]. In summary, landscape resources can be classified into physical and nonphysical resources, natural and artificial landscapes, tangible and nontangible landscapes, inherent and symbolic significance, as well as other symbolisms. Additionally, landscape resources are considered a dynamic system that is growing and evolving.

Carneiro et al. [22] explored the relationship between rural landscapes and experience, conducting empirical analysis on tourists who visited two villages in Spain. The results showed that the visual experience of the tangible landscape is a crucial experiential source; moreover, sound, smell, taste, and contexts associated with the past formed a quiet and relaxing intangible environmental atmosphere, which was also a critical experiential source and could be used to shape the countryside and attract tourists. Utilizing natural landscapes and artificial facilities can further bolster a travel destination's unique brand equity. Various factors attract visitors to a travel destination. For example, in an organic agriculture village, tourists can enjoy the beauty of biodiversity, such as in fern ecological zones, mud volcanoes, and waterfalls [23]. Moreover, people living in urban areas tend to seek a clean, pleasant, and comfortable environment in which to relax $[23,24]$. Additionally, farm-based products and activities and the relaxing atmosphere of organic agritourism can provide unique travel experiences for tourists [23,24]. Farm life has the power to provoke feelings of nostalgia [23,24]. People feel nostalgic for farm life, which takes them on a mental journey to visit a memory from their past [23]. Furthermore, people's attitudes toward nature have changed considerably. Considering the necessity of protecting the environment and the importance of maintaining ecological integrity [25], staying in organic agriculture villages has become an attractive option for people living in urban areas [23]. Visitors like the idea of relaxing in an agriculture-oriented property and enjoying its daily lifestyle.

In summary, landscape resources form the core foundation of organic agriculture village development. The effective utilization of these resources is critical to the success of such developments. In this study, natural, country, and artificial landscapes, as well as people's experiences of farm stays and organic farming, were evaluated.

\subsection{Brand Equity}

Branding is an effective method used by a company to differentiate its products from those of other companies. Moreover, it is a tool that an enterprise can used to strengthen its competitiveness. Through 
endearing a particular product or service to customers, an enterprise ensures that the intrinsic value of that product or service will be acknowledged. That value can be considered brand value for customers [26]. A brand can be considered a physical or service product for customers. The ultimate goal of marketing is to establish a high level of brand equity. Marketers attempt to create positive and favorable brand images because such images can generate positive attitudes toward the brand [27-29].

In terms of marketing strategies, brand equity is an effective tool for increasing differential competitiveness [12-14]. It refers to the added value endowed on products and services [12,27,30,31]. A strong brand identity can lead consumers to make brand associations, which in turn creates brand equity [12]. Brand equity has been adopted in the hospitality industry in recent years [15,32-34].

Brand equity comprises five elements: brand loyalty, brand awareness, perceived quality, brand association, and proprietary brand assets. Aaker [12] indicated that brand equity is manifested through the associations that consumers make with a brand, whereas brand association is the result of brand recognition. Many studies have used four dimensions-awareness, image, quality, and loyalty—as the basis for measuring brand equity [16,29,35-42]. Zavattaro et al. [43] conducted a qualitative study to assess a method for managing local brand equity, and they used brand awareness, perceived quality, brand loyalty, and brand association to evaluate local brand equity. Tran et al. [44] conducted a study on the brand equity of tourist destinations and adopted brand loyalty, brand awareness, perceived quality, and brand image to assess brand equity.

In the present study, the following dimensions were used to measure the brand equity of Luoshan Organic Agriculture Village: (1) awareness, (2) the image of organic farming, (3) quality, (4) loyalty, and (5) unique resources. Quality is the perception that customers have of the product or service of a brand, and in this study it comprised travel services, comprehensive facilities, and tourists' experience of organic farming. Images of organic farming comprised environmental sustainability, images of healthy tourism, and feelings when traveling to rural areas. Unique resources relate to an excellent geographical location and uniqueness of organic farming.

\section{Material and Methods}

\subsection{Framework}

All field crops require sunshine, air, water, and soil to grow. Climate change has an effect on the quality and quantity of food produced globally. Recently, food supply and food safety have been major topics in global public health. An increasing number of food-producing countries have promoted their food credentials to improve the competitiveness of their agricultural products [45].

Landscape resources are designed to attract admiration and appreciation. When a travel destination is appreciated by visitors as a unique attraction, its unique brand equity is strengthened $[46,47]$. Thode and Maskulka [48] asserted that consumers often rely upon a wine's place of origin when assessing its quality. Fernqvist and Ekelund [49] indicated that a brand's country of origin can influence consumers' perceptions of its products. Rajesh [50] examined the influence of tourists' perceptions of tourist environments (including the natural environment, historical and cultural environment, accessibility, facilities, relaxation, price, and value), which form their image of a destination in addition to satisfaction with and loyalty to it. Prayyag and Ryan [51] indicated that personal involvement influences destination image and place attachment, destination image influences satisfaction and place attachment, and place attachment influences satisfaction, which in turn influences revisit intention and appraisal. According to Dai et al. [11], from a conventional landscape-resource perspective, tourists' perceptions of landscape resources are not well understood. Tourists, through their mindscape of landscape resources, can value landscape resources. Various types of landscape resources (e.g., general, tourist-oriented, and popular-culture landscape resources) can help form city image through tourists' cultural experiences, thereby enhancing the city's authenticity, consistency, and popular culture as well as providing a reference for determining the positioning of an urban brand. The present study 
selected a travel destination and focused on the relationship between its landscape resources and brand equity. Figure 1 illustrates the research framework. Based on the research framework, the following hypothesis was proposed:

Hypothesis 1 (H1). Landscape resources do not positively affect brand equity.

\begin{tabular}{|c|c|c|}
\hline Landscape Resources & & Brand Equity \\
\hline $\begin{array}{c}\text { Natural Landscape } \\
\text { Country Landscape } \\
\text { Artificial Landscape } \\
\text { Experience of Farm Stay } \\
\text { Experience of Organic Farming }\end{array}$ & $\mathrm{H} 1$ & $\begin{array}{c}\text { Awareness } \\
\text { Loyalty } \\
\text { Quality } \\
\text { Image Regarding Organic Farming } \\
\text { Unique Resources }\end{array}$ \\
\hline
\end{tabular}

Figure 1. Research framework.

\subsection{Questionnaire Design and Data Collection}

Data were collected using a questionnaire survey administered to tourists in Luoshan Organic Agriculture Village. This questionnaire included three parts, namely the landscape resources of the travel destination, brand equity, and the respondents' background information. A 5-point Likert scale was adopted to measure participants' responses in relation to a group of categories in which people were asked to indicate how much they agreed or disagreed from least to most. In total, 258 of 258 questionnaires were completed by tourists to Luoshan Organic Agriculture Village for a valid response rate of $100 \%$.

\section{Results}

\subsection{Structural Analysis of the Sample}

The results revealed that $55.6 \%$ of respondents were female, and the majority were married ( $51.4 \%)$. Furthermore, respondents aged 31-40 years accounted for $28.3 \%$ followed by those aged 21-30 years who accounted for $23.3 \%$; notably, the majority of respondents fell into the $31-40$ years age group. Furthermore, $27.2 \%$ of the respondents were students, followed by military officers, public servants, and educational personnel (22.2\%). In terms of educational level, those with a bachelor's degree accounted for the largest proportion of the sample (49.4\%). In addition, 35\% of respondents earned less than NT $\$ 20,000$ per month, whereas $21.1 \%$ of respondents earned above NT $\$ 60,001$ per month.

\subsection{Landscape Resources}

Table 1 presents the results of the analysis of Luoshan Organic Agriculture Village's landscape resources, with average values between 3.80 and 4.67. Among these, organic farming ranked the highest, followed by fresh air and extensive views of the mountains. Luoshan Organic Agriculture Village was the first organic agriculture village in Taiwan; therefore, related agencies spent substantial amounts of money developing resources related to organic farming. Because the village is situated among the mountains and valleys of Eastern Hualien, its fresh air and extensive views of the mountains and other natural landscape resources have helped shape a natural and rural atmosphere. These resources are crucial factors that have attracted visitors to the village.

To determine the reliability of the scale, internal consistency was measured using Cronbach's alpha. The scale had five dimensions, namely natural landscape, country landscape, artificial landscape, experience of farm stays, and experience of organic farming, and they had Cronbach's alpha coefficients of $0.778,0.845,0.500,0.794$, and 0.703 , respectively. Country landscape ranked the highest, followed by experience of organic farming and natural landscape. This indicated that the Luoshan Organic 
Agriculture Village landscape resource scale had good internal consistency. Table 2 presents the results of the reliability analysis.

Table 1. Dimensions of Luoshan Organic Agriculture Village's landscape resources.

\begin{tabular}{cccc}
\hline Dimensions & Factors & Mean & Std. Deviation \\
\hline \multirow{3}{*}{ Natural landscape } & Luoshan waterfall & 4.35 & 0.72 \\
& Luoshan fish pond & 4.08 & 0.77 \\
& Luoshan mud volcano & 4.50 & 0.59 \\
& Fern ecological zone & 4.34 & 0.75 \\
\hline \multirow{2}{*}{ Country landscape } & Rural landscape & 4.41 & 0.67 \\
& Extensive views of the mountains & 4.52 & 0.66 \\
& Fresh air & 4.65 & 0.56 \\
\hline \multirow{2}{*}{ Artificial landscape } & Campsite & 3.80 & 0.92 \\
& Ancient mud houses & 4.20 & 0.77 \\
\hline \multirow{2}{*}{ Experience of farm stay } & Sampling of mud volcano bean curd & 4.22 & 0.72 \\
& Experience of farm stay & 4.20 & 0.70 \\
& Experience of rural living & 4.28 & 0.66 \\
\hline \multirow{2}{*}{ Experience of organic farming } & Experience of organic bread making & 4.32 & 0.65 \\
& Fragrant fried rice & 4.04 & 0.73 \\
& Organic farming & 4.67 & 0.55 \\
\hline
\end{tabular}

Table 2. Reliability analysis of Luoshan Organic Agriculture Village's landscape resources.

\begin{tabular}{cccc}
\hline Dimensions & Mean & Std. Deviation & Cronbach's $\alpha$ \\
\hline Natural landscape & 4.32 & 0.55 & 0.778 \\
Country landscape & 4.53 & 0.55 & 0.845 \\
Artificial landscape & 3.99 & 0.69 & 0.500 \\
Experience of farm stay & 4.23 & 0.59 & 0.794 \\
Experience of organic farming & 4.34 & 0.61 & 0.703 \\
\hline
\end{tabular}

\subsection{Brand Equity}

Table 3 presents the results of the analysis of Luoshan Organic Agriculture Village's brand equity. Overall, Luoshan Organic Agriculture Village enjoyed a high level of brand equity, ranging between 4.36 and 4.72. Respondents indicated that the strongest brand equity factor was environmental sustainability, followed by the uniqueness of organic farming and image of healthy tourism. Tourists to Luoshan Organic Agriculture Village recognize the importance of environmental sustainability, the uniqueness of organic farming, and image of healthy tourism to brand equity.

Table 3. Dimensions of brand equity.

\begin{tabular}{cccc}
\hline Dimensions & Factors & Mean & Std. Deviation \\
\hline Awareness & & 4.36 & 0.76 \\
Loyalty & & 4.36 & 0.71 \\
& & 4.52 & 0.66 \\
Quality & Service Quality & 4.36 & 0.72 \\
& Comprehensive facilities & 4.43 & 0.68 \\
Image regarding organic farming & Experience of organic farming & 4.72 & 0.57 \\
& Environmental sustainability & 4.56 & 0.60 \\
& Image of healthy tourism & 0.67 \\
Unique resources & Feelings of travelling to rural area & 4.46 & 0.80 \\
& Excellent geographical location & 4.21 & 0.63 \\
\hline
\end{tabular}


The brand equity scale had five dimensions, namely: awareness, loyalty, quality, image of organic farming, and unique resources, which had Cronbach's alpha coefficients of $0.64,0.84$, and 0.50 , respectively. This indicated that the brand equity scale had good internal consistency, as shown in Table 4.

Table 4. Reliability analysis of brand equity.

\begin{tabular}{cccc}
\hline Dimensions & Mean & Std. Deviation & Cronbach's $\alpha$ \\
\hline Awareness & 4.36 & 0.76 & - \\
Loyalty & 4.36 & 0.71 & - \\
Quality & 4.44 & 0.52 & 0.64 \\
Image regarding organic farming & 4.58 & 0.54 & 0.84 \\
Unique resources & 4.40 & 0.56 & 0.50 \\
\hline
\end{tabular}

\subsection{Cluster Analysis of Access to Environmental Information}

This study employed cluster analysis to segment tourists to Luoshan Organic Agriculture Village based on the frequency with which they obtain environmental information and their frequency of visiting organic agriculture villages. This analysis divided the tourists into two clusters: those with low and high access to environmental information. Table 5 presents the results.

Table 5. Cluster analysis of access to environmental information.

\begin{tabular}{ccccc}
\hline Variables & $\begin{array}{c}\text { Low-Access } \\
(\boldsymbol{n}=\mathbf{1 0 6})\end{array}$ & $\begin{array}{c}\text { High-Access } \\
(\boldsymbol{n}=\mathbf{1 4 9 )}\end{array}$ & F & Significance \\
\hline Frequency of getting information & 3.00 & 4.46 & 222.076 & 0.000 \\
Frequency of visiting organic agriculture village & 1.23 & 2.93 & 174.238 & 0.000 \\
\hline
\end{tabular}

\subsection{Relationships among Landscape Resources and Brand Equity}

To confirm whether access to environmental information moderated landscape resources and brand equity in Luoshan Organic Agriculture Village, this research classified the tourists into those with a low level of access to environmental information (i.e., the low-level cluster) and those with a high level of access to environmental information (i.e., the high-level cluster) before establishing a linear structural relationship model. The model was analyzed using the structural equation model analysis software package LISREL 8.52, and the results are presented in Figure 2. The numbers represent path coefficients, whereas those in brackets represent the $t$ values of the coefficients.

In the low-level cluster, under the absolute fit measures, the goodness-of-fit index (GFI) was 0.93 and the root mean square error of approximation (RMSEA) was 0.04 ; every measure was at a significant level. Among the incremental fit measures, the adjusted GFI (AGFI) was 0.98 , the normed fit index (NFI) was 0.97 , and the comparative fit index (CFI) was 1.00; all values fell within the ideal range. Among the parsimonious fit measures, the root mean square residual (RMR) was 0.05 . The path coefficient of landscape resources to brand equity was 0.65 , and $t$-value was 5.38 , reaching the significance level. These results falsify H1. The top two factors affecting landscape resources were experience of organic farming and natural landscape. In addition, two factors that influenced brand equity were derived: quality and unique resources.

In the high-level cluster, under the absolute fit measures, the GFI was 0.94 and the RMSEA was 0.07. Among the incremental fit measures, the AGFI was 0.89 , the NFI was 0.94 , and the CFI was 0.97; all values fell within the ideal range. Furthermore, the RMR was 0.05 among the parsimonious fit measures. The path coefficient of landscape resources to brand equity was 0.76 with a $t$-value of 5.18 , reaching the level of significance. These results also suggest that landscape resources positively affect brand equity. The low- and high-level clusters were proven to be moderators; Figures 2 and 3 show their moderating effects on the relationship between landscape resources and brand equity. For the high-level cluster, the moderating effect reached 0.76 , while the moderating effect of the low-level cluster was 0.65 ; 
the moderating effect of the high-level cluster is greater than that of the low-level cluster. The results revealed that the impact of landscape resources on brand equity varies with different levels of access to environmental information moderating the relationship between the two factors. Consequently, the level of access to environmental information is a moderator that influences the relationship between landscape resources and brand equity.

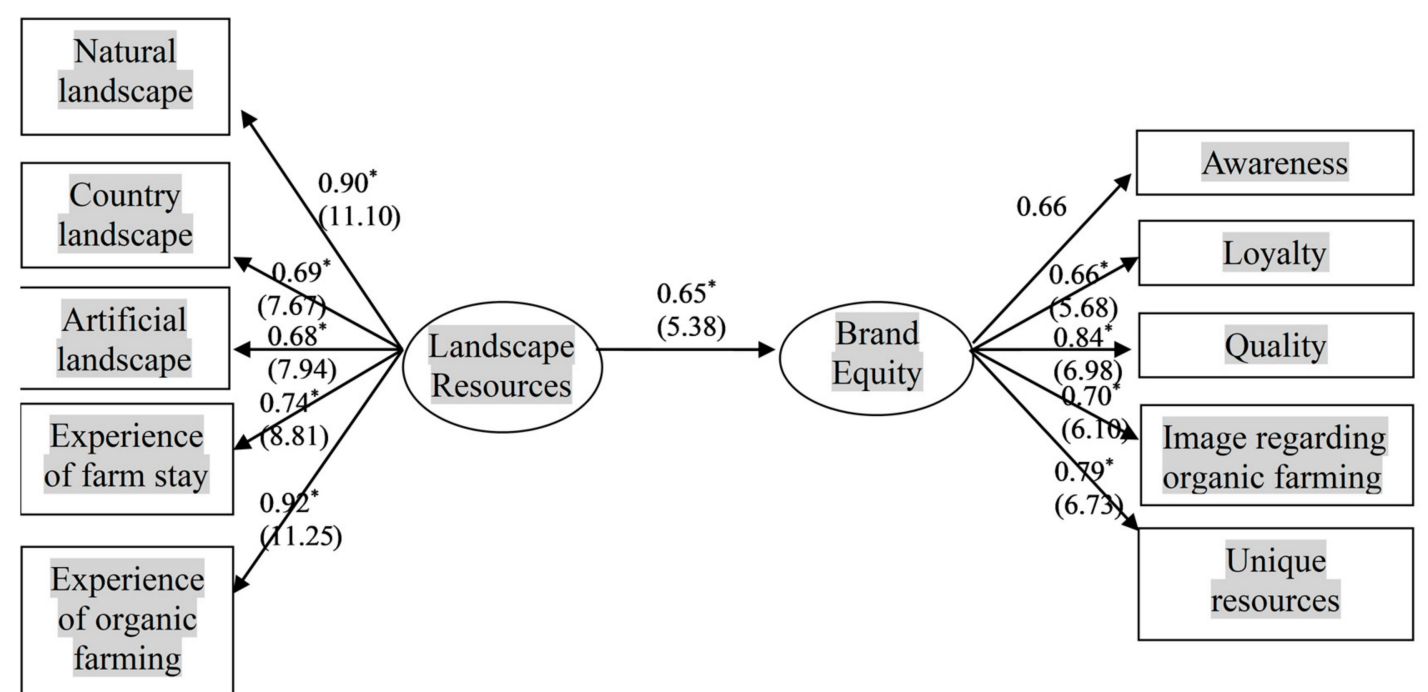

Figure 2. Relationships among landscape resources and brand equity in the group with a low level of access to environmental information.

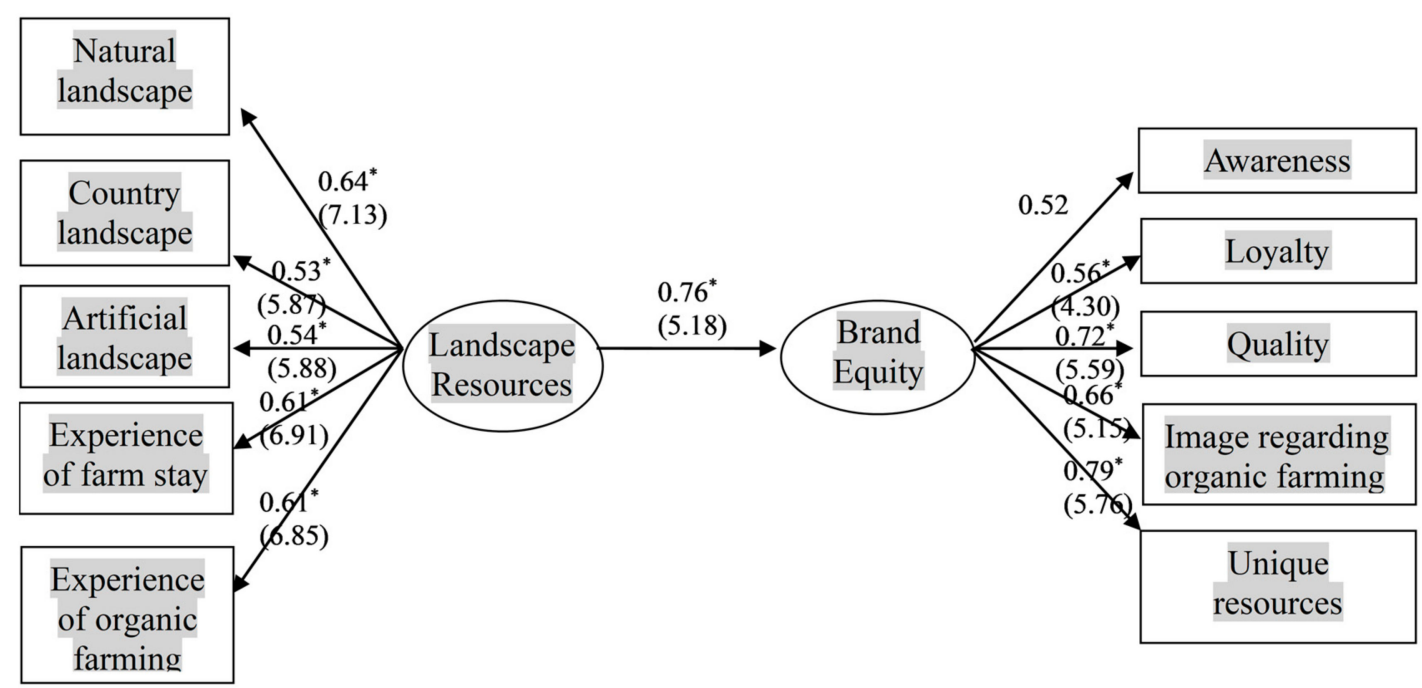

Figure 3. Relationships among landscape resources and brand equity in the group with a high level of access to environmental information.

\section{Discussion and Conclusions}

Brand equity is a crucial factor for differentiation. It is an effective method used by companies to differentiate their products from those of other companies. Furthermore, brand equity is a tool that an enterprise can use to strengthen its competitiveness through utilizing the landscape resources of a travel destination. The findings of this study indicated a high canonical correlation between landscape resources and brand equity. The results also indicated that Luoshan Organic Agriculture Village enjoys high brand equity, especially in terms of its environmental sustainability, uniqueness of organic farming, and image of healthy tourism. Consumers' perceptions of landscape resources help produce 
meaning and image, thereby forming a meaningful consumption landscape and further influencing brand equity, as well as indicating the importance of the consumption landscape. Regarding organic agricultural tourism, tangible landscape resources such as natural field scenery and organic agricultural experience and environment make tourists feel natural, healthy, and relaxed. This occurs through them participating in activities, experiencing the countryside lifestyle, and understanding the consumption meaning and value of an organic, nontoxic, sustainable environment, thereby further shaping the brand equity of organic agricultural tourism. Therefore, tourists' understanding of the importance of organic agricultural development is conducive to environmental sustainability.

In addition, access to environmental information had a significant moderating effect on the relationship between landscape resources and brand equity. To analyze how access to environmental information influences landscape resources and brand equity in Luoshan Organic Agriculture Village, a linear structural relationship was created in this study using the structural equation model analysis software package LISREL. The research results showed that with the moderation of high-level access to environmental information, the path coefficient of landscape resources to brand equity was 0.76 , which is greater than the corresponding coefficient with the moderation of low-level access to environmental information (i.e., 0.65). This suggests that landscape resources have a stronger impact on brand equity in the context of high-level access to environmental information compared with the impact of the moderation of low-level access to environmental information. Thus, access to environmental information has a moderating effect on the relationship between landscape resources and brand equity. The top three factors affecting landscape resources were the natural landscape, experience of organic farming, and experience of farm stays. In addition, two factors were derived that influenced brand equity: quality and unique resources.

Maximizing local economic benefit is also one of its goals for Ecotourism [52]. If the local people of Luoshan Organic Agriculture Village do not benefit from ecotourism development, they will not attach importance to protecting and developing organic agriculture tourism in the long term. In some cases, tourism has positive influences for conservation, particularly in well-managed protected areas, in terms of helping local citizens to generate their revenue via tourism [53-56]. Only when the protection of natural resources and the development of tourism are both implemented effectively can Organic Agriculture tourism be successful and sustainable.

Establishing the brand image of an organic agricultural environment can motivate tourists to recognize the importance of organic environments and inspire emotional connection with them. Hualien and Taitung have been called 'Taiwan's backyard' and are considered pure land in Taiwan. We suggest that organic agriculture in Hualien and Taitung is integrated with surrounding natural and cultural resources to shape the brand image of organic agriculture and environmental sustainability, and to help tourists better understand agricultural and rural tourism. This will enhance tourists' identification with environmental brands and the brand equity of organic agricultural tourism.

Because Luoshan Organic Agriculture Village was the first organic agriculture village in Taiwan, organic farming and related experiential activities were the core landscape resources for shaping the village's brand equity. Luoshan is located in the center of the East Rift Valley; with the rich natural resources of the area, such as mud volcanoes and waterfalls, ample potential exists for establishing brand equity in Luoshan Organic Agriculture Village. Further integrating tourism activities with organic farming will create greater economic value - this could be a critical development strategy for establishing a unique image for Luoshan Organic Agriculture Village.

\section{Restrictions}

Through an analysis that utilized linear structural equation modeling, it was revealed that the landscape resources of tourist destinations are a factor that affects brand equity, and that the level of access to environmental information is a moderator for the relationship between landscape resources and brand equity. In light of this study's research limitations, five suggestions are proposed for subsequent research. This study assumes that the relationship between landscape resources and brand 
equity is linear. Further research is needed to confirm whether the landscape resources of other organic agriculture villages also have a linear relationship with brand equity. Cluster analysis was conducted using level of access to environmental information as a variable (which constituted the analytical basis for the moderating effect of access to environmental information); however, cluster analysis can reduce intra-group variation, and whether this affects the analytical results is an issue that requires further clarification. This study mainly examined tangible landscape resources. Future research can include intangible resources or further analyze landscape resources from the perspective of consumption. In this study, an empirical analysis was conducted with tourists of the Luoshan organic village in Taiwan serving as research participants, and whether the research results are applicable to other organic agriculture villages is an issue that requires further clarification. Due to the geographical location of Luoshan organic village, the results of this study highlight the importance of unique resources. In this area, the issues worth studying include the kind of unique resources that other organic agriculture villages possess and whether landscape resources are also important factors that affect the brand equity of these villages.

Author Contributions: Conceptualization, Idea come from C.-C.S. and D.-J.L.; methodology, C.-C.S. has discussed with Y.-R.C. and D.-J.L.; software and validation by Y.-R.C. and C.-C.S. check it again; formal analysis, Y.-R.C.; investigation, Questionnaires Survey in support by D.-J.L.; resources, D.-J.L.; data curation, C.-C.S.; writing-original draft preparation, Y.-R.C.; writing-review and editing, C.-C.S.; visualization, C.-C.S.; supervision, C.-C.S.; project administration, C.-C.S. and Y.-R.C. All authors have read and agreed to the published version of the manuscript.

Funding: This research received no external funding.

Acknowledgments: We would like to express our sincere appreciation to the reviewers.

Conflicts of Interest: The authors declare no conflict of interest.

\section{References}

1. Chang, S.F.; Lee, S.S. The study of consumers shopping orientations in organic agricultural products. J. Leis. Recreat. Ind. Manag. 2009, 2, 1-15.

2. Raynor, E.J.; Coon, J.J; Swartz, T.M.; Morton, L.W.; Schacht, W.H.; Miller, J.R. Shifting cattle producer beliefs on stocking and invasive forage: Implications for grassland conservation. Rangel. Ecol. Manag. 2019, 72, 888-898. [CrossRef]

3. Saba, A.; Messina, F. Attitudes towards organic foods and risk/benefit perception associated with pesticides. Food Qual. Prefer. 2003, 14, 637-645. [CrossRef]

4. Taiwan Organic Information Portal. 2015 Statistics on the Number of Organic Farmers and the Area of Organic Farming; Taiwan Organic Information Portal: Taipei, Taiwan, 2019.

5. IFOAM. The Four Principles of Organic Agriclture; International Federal Organic Agriculture Movement (IFOAM): Bonn, Germany, 2020; Available online: https://www.ifoam.bio/why-organic/shaping-agriculture/ four-principles-organic (accessed on 31 August 2020).

6. Tourism Bureau. Statistics on Tourist Frequency for Major Recreation Areas in Taiwan in 2018; Tourism Bureau, Republic of China (Taiwan): Taipei, Taiwan, 2018.

7. Sauer, C.O. The Morphology of Landscape; California Press: Berkeley, CA, USA, 1925.

8. Meining, D.W. The Interpretation of Ordinary Landscape: Geographical Essays; Oxford University Press: New York, NY, USA, 1979.

9. Martin, G.J.; James, P.E. All Possible Worlds: A History of Geographical Ideas, 3rd ed.; John Wiley \& Sons: New York, NY, USA, 1993.

10. Bastian, O.; Stein, C.; Lupp, G.; Behrens, J.; Renner, C.; Grunewald, K. The appreciation of nature and landscape by tourism service providers and visitors in the Ore Mountains (Germany). Landsc. Online 2015, 41, 1-23. [CrossRef]

11. Dai, T.; Zhuang, T.; Yan, J.; Zhang, T. From landscape to mindscape: Spatial narration of touristic Amsterdam. Sustainability 2018, 10, 2623. [CrossRef]

12. Aaker, D.A. Managing Brand Equity: Capitalizing on the Value of a Brand Name; The Free Press: New York, NY, USA, 1991. 
13. Keller, K.L. Brand synthesis: The multidimensionality of brand knowledge. J. Consum. Res. 2003, 29, 595-600. [CrossRef]

14. Tasci, A.D.A.; Gartner, W.C.; Cavusgil, S.T. Conceptualization and operationalization of destination image. J. Hosp. Tour. Res. 2007, 31, 194-233. [CrossRef]

15. Boo, S.; Busser, J.; Baloglu, S. A model of customer-based brand equity and its application to multiple destinations. Tour. Manag. 2009, 30, 219-231. [CrossRef]

16. Konecnik, M.; Gartner, W.C. Customer-based brand equity for a destination. Ann. Tour. Res. 2007, 34, 400-421. [CrossRef]

17. Wagner, P.L.; Mikesell, M.W. Readings in Cultural Geography; University of Chicago Press: Chicago, IL, USA, 1962.

18. Daniel, S.; Cosgrove, D. The Iconography of Landscape; Cambridge University Press: Cambridge, MA, USA, 1988.

19. Stamp, L.D. A History of Land Use in Arid Regions; United Nation Education, Scientific and Cultural Organization: Paris, France, 1961.

20. Monkhouse, F.J. A Dictionary of Geography, 2nd ed.; Edward Amold: London, UK, 1970.

21. Samsudin, P.Y.; Maliki, N.Z. Preserving cultural landscape in homestay programme towards sustainable tourism: Brief critical review concept. Procedia Soc. Behav. Sci. 2015, 170, 433-441. [CrossRef]

22. Carneiro, M.J.; Lima, J.; Silva, A.L. Landscape and the rural tourism experience: Identifying key elements, addressing potential, and implications for the future. J. Sustain. Tour. 2015, 23, 1217-1235. [CrossRef]

23. Shen, C.C.; Liu, D.J.; Tseng, T.A. Establishing an organic agricultural tourism attachment model by integrating the means-end chain method and fuzzy aggregation operator. J. Outdoor Recreat. Study 2020, 33, 67-114.

24. Yang, C.Y.; Chang, T.Y. A study on the regulations, related to the organic leisure farmsbased on the amended provisions of the certification criteria for organic agricultural products and organic agricultural processed products perspetive. J. Tour. Leis. Manag. 2017, 5, 130-138.

25. Schulze, P. Ecological integrity and ecological health are not the same. In Engineering within Ecological Constraints; Karr, J.R., Ed.; The National Academies Press: Washington, DC, USA, 1996; pp. 97-110.

26. Kuvykaite, R.; Piligrimiene, Z. Consumer engagement into brand equity creation. Procedia Soc. Behav. Sci. 2014, 156, 479-483. [CrossRef]

27. Biel, A.L. How brand image drives brand equity. J. Advert. Res. 1992, 32, 6-12.

28. Barwise, P. Brand equity: Snark or boojum? Int. J. Res. Mark. 1993, 10, 93-104. [CrossRef]

29. Buil, I.; de Chernatony, L.; Martínez, E. Examining the role of advertising and sales promotions in brand equity creation. J. Bus. Res. 2013, 66, 115-122. [CrossRef]

30. Farquhar, P.H. Managing brand equity. Mark. Res. 1989, 1, 24-33.

31. Kamakura, A.W.; Russell, G.J. Measuring brand value with scanner data. Int. J. Res. Mark. 1993, 10, 9-22. [CrossRef]

32. Bailey, R.; Ball, S. An exploration of the meanings of hotel brand equity. Serv. Ind. J. 2006, 26, 15-38. [CrossRef]

33. Woodside, A.G.; Cruickshank, B.F.; Dehuang, N. Stories visitors tell about Italian cities as destination icons. Tour. Manag. 2007, 28, 162-174. [CrossRef]

34. Sun, L.; Ghiselli, R.F. Developing the conceptual model of brand equity in the hotel industry based on Aker's perspective. J. Qual. Assur. Hosp. Tour. 2010, 11, 147-161. [CrossRef]

35. Cobb-Walgren, C.J.; Ruble, C.A.; Donthu, N. Brand equity, brand preference, and purchase intent. J. Advert. 1995, 24, 25-40. [CrossRef]

36. Yoo, B.; Lee, S. An examination of selected marketing mix elements and brand equity. Acad. Market. Sci. 2000, 28, 195-211. [CrossRef]

37. Yoo, B.; Donthu, N. Developing and validating multidimensional consumer-based brand equity scale. J. Bus. Res. 2001, 52, 1-14. [CrossRef]

38. Washburn, J.H.; Plank, R.E. Measuring brand equity: An evaluation of a consumer based brand equity scale. J. Mark. Theory Pract. 2002, 10, 46-62. [CrossRef]

39. Ashill, N.J.; Sinha, A. An exploratory study into the impact of components of brand equity and country of origin effects on purchase intention. J. Asia-Pac. Bus. 2004, 5, 27-43. [CrossRef]

40. Pappu, R.; Queste, P.; Cooksey, R.W. Consumer-based brand equity: Improving the measurement-Empirical evidence. J. Prod. Brand Manag. 2005, 14, 143-154. [CrossRef]

41. Tong, X.; Hawley, J.M. Measuring customer-based brand equity: Empirical evidence from the sportswear market in China. J. Prod. Brand Manag. 2009, 18, 262-271. [CrossRef] 
42. Lee, J.S.; Back, K.J. Reexamination of attendee-based brand equity. Tour. Manag. 2010, 31, 395-401. [CrossRef]

43. Zavattaro, S.M.; Daspit, J.J.; Adams, F.G. Assessing managerial methods for evaluating place brand equity: A qualitative investigation. Tour. Manag. 2015, 47, 11-21. [CrossRef]

44. Tran, V.T.; Nguyen, N.P.; Tran, P.T.K.; Tran, T.N.; Huynh, T.T.P. Brand equity in a tourism destination: A case study of domestic tourists in Hoi An city, Vietnam. Tour. Rev. 2019, 74, 704-720. [CrossRef]

45. Papadopoulos, N. Place branding: Evolution, meaning and implications. Place Brand. 2004, 1, 36-49. [CrossRef]

46. Morgan, N.; Pritchard, A.; Pride, R. Introduction. In Destination Branding: Creating the Unique Destination Proposition; Morgan, N., Pritchard, A., Pride, R., Eds.; Butterworth-Heinemann: Oxford, UK, 2002.

47. Dinnie, K. Country-of-origin 1965-2004: A literature review. J. Cust. Behav. 2004, 3, 165-213. [CrossRef]

48. Thode, S.F.; Maskulka, J.M. Place-based marketing strategies, brand equity and vineyard valuation. J. Prod. Brand Manag. 1998, 7, 379-399. [CrossRef]

49. Fernqvist, F.; Ekelund, L. Credence and the effect on consumer liking of food-A review. Food Qual. Prefer. 2014, 32, 340-353. [CrossRef]

50. Rajesh, R. Impact of tourist perceptions, destination image, and tourist satisfaction on destination loyalty: A conceptual model. PASON. Revista de Turismo y Patimonio Cultural 2013, 11, 67-78. [CrossRef]

51. Prayyag, G.; Ryan, C. Antecedents of tourists' loyalty to Mauritius: The role and influence of destination image, place attachment, personal involvement, and satisfaction. J. Travel Res. 2012, 51, 342-356. [CrossRef]

52. Li, F.; Zhu, Q.; Yang, Z. Birding tourism development in Sichuan, China. Tour. Econ. 2013, 19, $257-273$. [CrossRef]

53. Brightsmith, D.J.; Stronza, A.; Holle, K. Ecotourism, conservation biology and volunteer tourism: A mutually beneficial triumvirate. Biol. Conserv. 2008, 141, 2832-2842. [CrossRef]

54. Buckley, R.C.; Castley, J.G.; Pegas Fde, V.; Mossaz, A.C.; Steven, R. A population accounting approach to assess tourism contributions to conservation of IUCN-Redlisted mammal species. PLoS ONE 2012, 7, e44134. [CrossRef] [PubMed]

55. Morrison, C.; Simpkins, C.A.; Castley, J.G.; Buckley, R.C. Tourism and the conservation of critically endangered frogs. PLoS ONE 2012, 7, e43757. [CrossRef] [PubMed]

56. Steven, R.; Castley, J.G. Tourism as a threat to critically endangered and endangered birds: Global patterns and trends in conservation hotspots. Biodivers. Conserv. 2013, 22, 1063-1082. [CrossRef] 